\title{
Analysis of Students Learning Difficulties in Advanced Differential Equation Courses Reviewed from the Use of Learning Media During the Covid-19 Pandemic
}

\author{
Inayah Rizki Khaesarani* \\ Mathematics Education Department, State Islamic University of North Sumatra, Indonesia \\ *inayahrizki56@gmail.com
}

\begin{abstract}
ABSTRAK
Ketidakmampuan mahasiswa dalam menguasai konsep materi persamaan diferensial lanjut menimbulkan faktor internal dan eksternal yang terbentuk pada dirinya sehingga perlu membutuhkan dorongan berupa penggunaan media pembelajaran yang efektif agar pembelajaran di kelas menjadi semakin menarik perhatian mahasiswa. Media pembelajaran daring yang digunakan berupa zoom, video pembelajaran secara offline ataupun online, Elearning, dan lain-lain. Tujuan dari penelitian ini adalah untuk mengidentifikasi dan mendeskripsikan kesulitan belajar mahasiswa pada mata kuliah persamaan diferensial lanjut ditinjau dari penggunaan media pembelajaran selama masa pandemi Covid-19. Jenis penelitian yang digunakan adalah penelitian kualitatif dengan pendekatan deskriptif. Hasil penelitian menunjukkan dari ketiga sub bab materi, mahasiswa sangat mengalami kesulitan belajar pada materi metode numerik untuk menyelesaikan persamaan-persamaan diferensial orde pertama. Dalam materi ini, mahasiswa masih kurang teliti dalam menjawab soal $(58,1 \%)$. Karena mahasiswa belum mampu mengidentifikasi jenis metode yang akan digunakan dalam menyelesaikan soal, maka mahasiswa butuh media pembelajaran daring yang dinilai efektif bagi pembelajaran matematika, seperti video pembelajaran offline (71\%) sebagai solusi untuk menghemat kuota internet. Dengan demikian, maka penelitian ini bermanfaat bagi pendidik/dosen dalam mengamati kondisi kesulitan belajar mahasiswa mengingat penggunaan media pembelajaran yang digunakan untuk memotivasi mahasiswa agar aktif dalam mempelajari mata kuliah persamaan diferensial lanjut selama masa pandemi Covid-19.
\end{abstract}

Kata kunci: Covid-19, Kesulitan belajar, Media Pembelajaran, Pembelajaran Daring, Persamaan Diferensial Lanjut.

\begin{abstract}
The inability of students to master the material concept of the advanced differential equation gives rise to internal and external factors that are formed in them so that it needs to require encouragement as effective use of learning media so that learning in the classroom becomes increasingly attractive to students. We used online learning media as zoom, offline or online learning videos, E-learning, and others. This research aimed to identify and describe students learning difficulties in advanced differential equation courses in terms of the use of learning media during the Covid-19 pandemic. The type of research used is qualitative research, with a descriptive approach. Results showed that students have great difficulty learning numerical methods to solve first-order differential equations from all three sub-chapters of matter. In this material, students are still less careful in answering questions $(58,1 \%)$. Because students could not identify the type of methods used to solve problems, students need online learning media that are effective for math learning, such as offline learning videos $(71 \%)$, as a solution to save internet quotas. So, this research is useful for educators/lecturers in observing the condition of student learning difficulties given the use of learning media used to motivate students to be active in learning advanced differential equation courses during the Covid-19 pandemic.
\end{abstract}

Keywords: advanced differential equation, covid-19, learning difficulties, learning media, online learning.

Received: 2021-10-27

/ Accepted: 2021-11-04

/ Published: 2021-11-15

\section{Introduction}

A differential equation is an equation that involves a function to be sought, and it is derivative (Bronson \& Costa, 2007). In addition, the definition of a differential equation is an equation of a function $y(x)$ that involves the derivative of the function $y^{\prime}(x)$ on one or more variables (Aziz, 2020). Using differential equations aims to express a complex relationship between one dependent variable and more independent variables (Oktavia \& Khotimah, 2016). Its 
application used differential equations in various fields, such as physics, biology, chemistry, economics, engineering, etc. It is suggested that differential equations have a broad application of disciplines. One of them is to build a mathematical model of natural phenomena by finding the best solution in solving the problem at hand.

In college, they use differential equations as compulsory courses that students of the S-1 Mathematics Education study program must take. I divided the differential equation into two, namely basic differential equation and advanced differential equation. In this study, the researchers will examine advanced differential equations in depth. I advanced differential equation courses of a basic differential equation. To complete this course, students must pass the basic differential equation course at least B. The materials studied in this course include (1) the differential equation system; (2) matrix; (3) $e^{A t}$; (4) reduction of a linear differential equation into a system of one-sequence equations; (5) solution of linear differential equation with constant coefficients through matrix methods; (6) numerical methods for solving first-rate differential equation; (7) Laplace Transform and it's opposite; and (8) the solution of differential equation with Laplace Transform. To master the differential equation of the course, they require students to master prerequisite materials, such as differential calculus and integral calculus. It is because something closely related to the course differential equation to derivative and integral functions. Suppose students do not master differential and integral concepts, likely. In that case, students cannot master advanced differential equation materials well, and then students will have difficulty solving easy or difficult problems in this course.

Based on the results of the odd semester of final test in 2020/2021 in advanced differential equation courses in the PMM-2 class mentioned that 36 out they declared of 40 people graduated with a pass value of $\geq 70$ people. I alleged this because students cheat with smarter friends so that the grades are above graduation grades. Of course, this harms math learning, especially online learning today. The problem of cheating on each other is like this, and surely students have difficulty learning and cheating with smarter friends to get good grades. Thus, the occurrence of dishonesty in online learning is now common.

Research shows they divide the factors that support the occurrence of cheating behavior into two, namely from internal and external. Internal factors, such as laziness, a pleasure to praise if you have an advantage, lack of motivation to learn, fear of competition, always worry if grades become low, have important principles to pass on a mandatory course, and so on. Meanwhile, external factors, such as lack of active learning, being a family request, the stress of mental disorders, environmental influences and close friends, being intimidated by smarter friends, elusive problems so easy to give up in response to it, the inability of reason to digest any material studied (Kurniasih, Limbong, \& Handayani, 2019). In addition, self-efficacy factors also harm cheating activities. If students have increased self-efficacy, cheating behavior decreases and opposite. Parents and teachers should be able to actively encourage students not to cheat on each other to reduce cheating behavior in the school environment (Anitasari et al., 2021). So, we can conclude that online learning during the current pandemic can trigger fraudulent behavior between students to get good grades so as not to repeat courses taken the following year.

Learning difficulties are heterogeneous situations that manifest as learning difficulties in one or more fundamental psychological functions (Oktavia \& Khotimah, 2016). Many factors influence students learning difficulties. Learning difficulties can divide into two, namely 
developmental-related learning difficulties (including motor impairment, communication difficulties, and difficulties in social behavior change) and academic learning difficulties (including mastery of skills in reading, writing, and math comprehension) (Abdurrahman, 2010). Students still have many difficulties applying differential equations, such as difficulty applying formulas or algorithms that have been taught. In addition, learning differential equations is difficult because the factors of learning difficulties lie in understanding the concept of equations, function concepts, and function derivatives so that to plan the learning of differential equation well, students must understand the concept of material well and thoroughly to build a concept of a differential equation so that it is easy to apply in everyday life (Ningsih \& Rohana, 2018).

According to Jamal, two factors, namely internal and external factors, cause students learning difficulties. Internal factors caused such as health, talents and interests, motivation, intelligence, and so on. As for external factors, the cause is from the family environment, community environment, school environment. Students still have difficulty in finding a concept. There are three contributing factors: perception (mathematical calculation), intervention, and extrapolation of implementing the teaching and learning process will determine the extent of the success achieved in mathematics subjects (Jamal, 2014). It is supported by research Oktavia \& Khotimah (2016) stating that the student is having difficulty, difficulty first understanding concepts which include: (1) difficulty planning common characteristics or forms of the differential equation; (2) difficulty in determining different equation solving techniques. Two difficulties applying concepts consist (1) difficulty in the calculation steps; (2) difficulties in the prerequisite material. The factors cause students to experience difficulties, the first intrinsic factor, namely: lack of learning activities, difficulty remembering formulas, bad habits, lack of problem training, lack of learning motivation, inappropriate educational background. The second factor is irrelevant, namely, being too active in social activities in the community.

Thus, it can conclude that students experience two factors of symptoms/phenomena in the teaching and learning process in the classroom, among others: factors from within the student, such as difficulty in determining the formula used, the material have not been thoroughly mastered, easy to give up in answering difficult questions, and lack of competitiveness with classmates, and lack of motivation to learn in the classroom. Meanwhile, for outside the student, such as non-academic activities off-campus, students often engage in it without prioritizing the lectures they are attending, causing low grades and laziness to learn to increase.

For the current implementation, the Indonesian government made an online implementation policy through the Circular Letter of the Minister of Education and Culture of the Republic of Indonesia Number 4 of 2020 on implementing Education in the Covid-19 Emergency Period and strengthened by the Circular Letter of the Directorate General Number 15 of 2020 on guidelines for implementing BDR during the Covid-19 emergency period (Khurriyati et al., 2021). I do this to prevent the spread of Covid-19 is increasingly widespread. So that it affects the application of learning conducted online through various platforms available, research shows that learners rate math learning to use online media effectively $(23,3 \%)$, most of them rate it as effective (46,7\%), and mediocre rates $(20 \%)$. However, some learners consider online learning ineffective $(10 \%)$ and absolutely none $(0 \%)$ who rate it very ineffective. To improve this, educators must meet ten suggestions from respondents so that learning can run well. One suggestion that learning is more effective is to minimize material delivery as heavy videos to save quotas. I mention students need learning videos that can save quotas. Every downloaded video must take care of learners' internet quota, so the government needs to allocate education 


\section{AlphaMath \\ Journal of Mathematics Education, 7(2) November 2021}

funds for students' internet quotas during online learning (Mustakim, 2020). Thus, lecturers/educators must be innovative in using online learning media in the classroom to balance the composition of learning. It is intended so that learning is not boring and increasingly attracts the attention of learners to keep learning even from a distance. Online learning certainly makes educators/lecturers go the extra mile so that the learning it brings is not monotonous and is ordinary by learners. In addition, educators/lecturers must attend training or seminars from educational institutions to help educators/lecturers improve the quality of online learning during the Covid-19 pandemic.

Some studies have examined advanced differential equations, such as research conducted by (Tsurayya \& Kurnianingrum, 2021), (Nurlaili \& Rifanti, 2020), and (Oktavia \& Khotimah, 2016). However, none of these studies analyzed students learning difficulties in advanced differential equation courses reviewed from learning media during the Covid-19 pandemic. They show the difference between the research studied and other studies. Thus, the purpose of this study is to identify and describe the learning difficulties of students Mathematics Education Department in studying advanced differential equation courses in view of the use of learning media used by lecturers during the Covid-19 pandemic. And useful to increase student learning motivation to be active in studying advanced differential equation courses during online learning.

\section{Methods}

The type of research used is qualitative research with a descriptive approach. I conducted the study online from December 2020 to January 2021. The research population is a student of the Mathematics Education Department of the State Islamic University of North Sumatra class 2018 who has (1) graduated from the elementary differential equation course at least B; (2) still taking advanced differential equation course; (3) aged 19-21 years; (5) able to communicate politely through online; (4) be willing to be involved in research. Sampling technique using purposive sampling, where respondents have met the criteria set by the researcher so that 31 students as a research subject.

The research procedure begins with creating google forms by entering all research questions to get the required data. Then, the researcher contacted the research subject via WhatsApp personal chat to get approval from the respondents to be involved in the study. Next, respondents filled out all questions via the google forms link shared via WhatsApp personal chat. After collecting the required data, the researcher would like to thank all respondents for the opportunity given to cooperate in completing the research.

Research instruments are researchers themselves who have tested their validity. The data analysis techniques used are questionnaires and brief interviews online. I gave questionnaires using checklist scales to make it easier for researchers to get primary data. The study used Google forms online as the primary source and relevant source as a source of support. The questionnaire amounted to 10 (ten) questions where there were 6 (six) questions related to advanced differential equation material, 3 (three) questions related to the effectiveness media used by lecturers during online lectures, and 1 (one) question related to impressions and messages during the advanced differential equation learning course. After obtaining all the data needed, the researchers analyzed the questionnaire responses and interviews in google forms. The response provided from google forms as a circle diagram has written the percentage of all questions given. Thus, it makes it easier for researchers to analyze the results of research 
conducted online. After that, the researchers turned the circle diagram into a table to make it easier to read. Material testing comprises three sub-chapters, namely (1) solution of linear differential equation with constant coefficients with matrix methods; (2) numerical methods for solving first-rate differential equation; and (3) the Laplace Transform.

\section{Result and Discussion}

In this study, the researcher collected information through a questionnaire containing 10 (ten) questions with details: 6 (six) questions related to advanced differential equation, 3 (three) questions related to the effectiveness of media used by teaching lecturers during online lectures, and 1 (one) question related to impressions and messages during online lectures. Follow the learning of the advanced differential equation course. The following will describe the results and discussion based on the primary data obtained. For more details, we can see it in Table 1. and Table 2. below:

\section{Learning Difficulties}

Table 1. Student Learning Difficulties in each material

\begin{tabular}{|c|c|c|}
\hline Subjects & Learning difficulty indicator & Percentage $(\%)$ \\
\hline $\begin{array}{l}\text { Solution of linear differential equation with } \\
\text { constant coefficients with matrix methods }\end{array}$ & Change to a matrix equation & 10 \\
\hline $\begin{array}{l}\text { Solution of linear differential equation with } \\
\text { constant coefficients with matrix methods }\end{array}$ & Looking for $e^{A t}$ & 43,3 \\
\hline $\begin{array}{l}\text { Solution of linear differential equation with } \\
\text { constant coefficients with matrix methods }\end{array}$ & $\begin{array}{l}\text { Looking for characteristic } \\
\text { equations }\end{array}$ & 0,1 \\
\hline $\begin{array}{l}\text { Solution of linear differential equation with } \\
\text { constant coefficients with matrix methods }\end{array}$ & Looking for values $\alpha_{1} \& \alpha_{2}$ & 13,3 \\
\hline $\begin{array}{l}\text { Solution of linear differential equation with } \\
\text { constant coefficients with matrix methods }\end{array}$ & $\begin{array}{c}\text { Determine which solution to } \\
\text { use }\end{array}$ & 33,3 \\
\hline $\begin{array}{l}\text { A numerical method for solving first-rate } \\
\text { differential equation }\end{array}$ & $\begin{array}{l}\text { Lack of research in } \\
\text { answering questions }\end{array}$ & 58,1 \\
\hline $\begin{array}{l}\text { A numerical method for solving first-rate } \\
\text { differential equation }\end{array}$ & $\begin{array}{l}\text { Misrepresent the problem } \\
\text { and enter the numbers }\end{array}$ & 35,5 \\
\hline $\begin{array}{l}\text { A numerical method for solving first-rate } \\
\text { differential equation }\end{array}$ & $\begin{array}{l}\text { The formula used is } \\
\text { inaccurate }\end{array}$ & 6,5 \\
\hline Laplace Transform & $\begin{array}{l}\text { Understand and solve } \\
\text { problems well without } \\
\text { having difficulties }\end{array}$ & 19,4 \\
\hline Laplace Transform & $\begin{array}{l}\text { Don't understand the } \\
\text { meaning of the matter }\end{array}$ & 32,3 \\
\hline Laplace Transform & $\begin{array}{l}\text { I don't know the technique } \\
\text { for solving the problem }\end{array}$ & 48,4 \\
\hline
\end{tabular}

From the table above, I get that in the solution material of linear differential equation with constant coefficient with matrix methods, students have difficulty finding values with the 


\section{AlphaMath \\ Journal of Mathematics Education, 7(2) November 2021}

highest percentage of learning difficulty indicators, $43,3 \%$. In the previous material, students have not understood the concept thoroughly, so they have difficulty answering questions given by lecturers. Similarly, Ningsih \& Rohana (2018) stated that understanding the concept of the ordinary differential equation of students is at the stage of action where students can solve problems related to the ordinary differential equation of simple homogeneous one-order with errors in integral principles and derivatives of logarithms and exponent functions. Students should first master the material of integral calculus and differential calculus so that students do not have difficulty answering the questions given. When facing the exam, students can complete all the questions given properly and carefully. It is what we should build so that the foundation of science that is built becomes strong.

In addition, the fundamental error of students in solving the material of the first-order linear equation using Watson criteria lies in the procedures inaccuracy performed, resulting in errors in the solution to integral problems. As for other supporting factors, such as lack of accuracy in reading and understanding the problem, lack of understanding of the concept of the material given, embarrassed to ask if there is something that is not understood, less active in doing problem training, so it is easy to give up. Thus, it can say that the main error of learning difficulties in first-order linear equation materials using Watson's criteria is in the student's inability to understand concepts and master previous material so that the difficulty in answering in problems (Nurlaili \& Rifanti, 2020).

Then presented numerical method material to solve the first-order differential equation, students had difficulty understanding the problem with a percentage reaching $58,1 \%$. The material presented is quite difficult for students to understand if students do not have accuracy and accuracy in understanding and answering questions. So that the student answers on the original without correcting repeated answers to the material tested, this material takes the ability to understand wonderful concepts so that students' cognitive style increases.

The research conducted by Tsurayya \& Kurnianingrum (2021) demonstrates the ability to understand the concepts of 36 students in solving differential equations in terms of their overall cognitive style of $46,50 \%$, which is still relatively low. Although still relatively low, in the overall understanding of the concept, students have reached a good category on each indicator. And when viewed from the ability of cognitive style, students with independent field cognitive style have better abilities than students who have a dependent field cognitive style. With this research, we know that students also can understand original concepts depending on the cognitive style used by their users. Therefore, the more we can hone the ability to understand concepts through cognitive style, the sharper our understanding of a material described by lecturers. And it can also use this as an alternative in solving the problem of student learning difficulties in advanced differential equations.

In the Laplace Transform material, the major factor of students experiencing learning difficulties lies in the student's inability to use the right techniques in solving problems, with a percentage reaching $48,8 \%$. It is because students do not know how to determine the Laplace Transform properly. It determines the Laplace Transform divided into two, namely manipulating the denominator and manipulating the numerator. Each way to determine the material of Laplace Transform, of course, has techniques for solving problems. If students cannot solve the problem, then the student does not know the right technique to find the solution to the problem in the material. It's also in line with (Bronson \& Costa, 2007) stated mistakes 
made by students involve procedures in recognizing determination in solving Laplace Transform problems appropriately.

According to Yusnanda, Helmi, \& Yudhi (2019), Laplace Transform can change to solve the ordinary linear differential equation problem that cannot be solved using Laplace Transform. The trick is to convert differential equations into functions in those variables. We then changed the desired function by changing the Laplace Transform modification in reverse to get a solution of a given differential equation.

Use of Learning Media

Table 2. Use of Learning Media During the Covid-19 Pandemic

\begin{tabular}{|c|c|c|}
\hline Subjects & Indicator & Percentage $(\%)$ \\
\hline $\begin{array}{l}\text { Learning media that is considered effective in } \\
\text { online learning }\end{array}$ & Video conference Zoom & 64,5 \\
\hline $\begin{array}{l}\text { Learning media that is considered effective in } \\
\text { online learning }\end{array}$ & Offline learning videos & 71 \\
\hline $\begin{array}{c}\text { Learning media that is considered effective in } \\
\text { online learning }\end{array}$ & WhatsApp Group & 45,2 \\
\hline $\begin{array}{c}\text { Learning media that is considered effective in } \\
\text { online learning }\end{array}$ & E-learning & 22,6 \\
\hline The quality of teaching materials used by lecturers & Not qualified & 0 \\
\hline The quality of teaching materials used by lecturers & Lack of quality & 3,2 \\
\hline The quality of teaching materials used by lecturers & Quite quality & 74,2 \\
\hline The quality of teaching materials used by lecturers & Very qualified & 22,6 \\
\hline $\begin{array}{l}\text { Material delivered through the medium of } \\
\text { learning can be understood }\end{array}$ & $\begin{array}{l}\text { Students can understand the } \\
\text { material delivered by } \\
\text { lecturers through the } \\
\text { learning media used }\end{array}$ & 61,3 \\
\hline $\begin{array}{l}\text { Material delivered through the medium of } \\
\text { learning can be understood }\end{array}$ & $\begin{array}{l}\text { Students cannot understand } \\
\text { the material delivered by } \\
\text { lecturers through the } \\
\text { learning media used. }\end{array}$ & 38,7 \\
\hline
\end{tabular}

Based on the table above, learning media that is effective in online learning is offline learning videos. It is because the indicator reaches the highest percentage, which is $71 \%$. Students think it can play repeatedly offline learning videos without having to issue quotas or data packages, thus saving their data plans. It's also in line with (Mustakim, 2020) said to improve the quality of online learning during the pandemic. One of them is to reduce explaining subject matter in videos that have a large size to save internet quotas.

A lecturer certainly has the quality of teaching materials that are effective for online learning. Students assess those lecturers have sufficient quality in using teaching materials to run smoothly according to learning objectives. We can see the quality of teaching materials used 
by lecturers from the accuracy of lecturers choosing to learn media. If it is as video, lecturers try hard to keep making videos more attractive to students. Relevant research shows that video media is the most precise and accurate learning medium in conveying messages and will help learners understand. With the video media, learners will better understand the material delivered by educators through the impression of a screened film to achieve the learning goals planned by educators/lecturers (Yudianto, 2017).

Thus, the material that is delivered is also easily understood by students. I got this from table 2 . with a percentage of $61,3 \%$. Lecturers who master differential equation courses further strive so that the material delivered to students is not convoluted, directly to the point to be delivered, prepare good grammar, and use images and tables on the PowerPoint to clarify the material to be delivered.

\section{Interview Results}

Interviews take the form of essays through Google forms where research subjects freely express their opinions about impressions and suggestions on advanced differential equation learning during the semester. So, it found an answer as a weak point of online learning during the Covid19 pandemic. Then, there will be answers from 10 respondents, namely:

Respondent 1: The impression during the lecturer, I was quite enthusiastic to follow the learning of advanced differential equation because the lecturer explained offline-based videos so that when there is a section that I do not understand, I can repeat the video and, in the video, the lecturer also describes the steps of solving the problem by the playbook. My advice for future methods like this can continue to be done by lecturers, considering that advanced differential equation courses are difficult to understand.

Respondent 2: The lecturer in question is quite good at delivering his material online, but the time is too short in the collection of tasks.

Respondent 3: I am less eager to do the task because I did not understand the material described by the lecturer.

Respondent 4: Learning videos are better in pandemic times because learning videos are easier to understand.

Respondent 5: It would be better to use a media meeting platform such as google meet so that the questions asked are fresher and answered clearly.

Respondent 6: It can occasionally use my advice in the teaching and learning process using zoom to face directly with lecturers. But don't do it too often because zooming too much drains my internet quota. The impression of this one-semester lecture is enough to add extensive knowledge and insight to me.

Respondent 7: Alhamdulillah, amazing. Difficulty only if when meeting lecturers does not make a video explanation for the material. Honestly, I still do not understand if I only read the PowerPoint form file provided by the master lecturer. For the rest, I am happy and feel challenged if I do the training questions given by the teacher lecturer. 
INAYAH RIZKI KHAESARANI

Analysis of Students Learning Difficulties in Advanced Differential Equation Courses

Respondent 8: I hopefully improved the advice by providing learning videos or a more creative PowerPoint. The impression while learning advanced differential equations is very pleasant, although sometimes there is a material that I do not understand.

Respondent 9: Today's lectures are very impressive because we have to wait for teaching materials and assignments given by lecturers every day.

Respondent 10: My impression is that learning is quite effective when compared to other courses. My advice is that it would be better to use Zoom to discuss the difficulties students face in understanding each material provided by the teacher.

We can conclude from the explanation above those students like learning media as learning videos (offline or online). Because this learning media is very suitable for use when online learning and lecturers often provide material explanations with learning media as learning videos, students are very interested and like the learning media used. In terms of its advantages, of course, learning media provides benefits and convenience for its users, but surely learning media also has shortcomings. One of them is the waste of internet quotas issued by students to download or watch the video, which is also a problem for students. It's also stated by Nuryadi \& Bahtiar (2017), interactive math learning media (Adobe Flash CS5) can increase student learning motivation by $7,14 \%$, with an initial score of $71,78 \%$ and a final score of $78,92 \%$. After applying the learning media in class, it has been proven that students learning motivation increases significantly, and the development of this learning media has met the effective criteria for online learning. So that interactive mathematical learning media used can support online learning effectively during pandemic times.

In addition, research by (Trisniawati, et al., 2021) said the implementation of online learning to use the Online Learning System (OLS) in the pandemic period has a positive impact on math learning outcomes in the classroom. The results showed that the average quiz and assignment scores in class $3 \mathrm{~A}$ were 83.27 and 72.90 . Average quiz scores and average assignment scores in class $3 \mathrm{~F}$ were 83.56 and 70.67 . So that student learning outcomes in both classes fall into the category of the use of OLS in learning well implemented and effectively carried out in online learning during the Covid-19 pandemic.

So, many learning media are effective to be used in online learning, especially math learning. Educators/lecturers must be innovative in channeling ideas or ideas in making innovative learning media to attract the attention of students and have good quality when used in math learning. That way, the better the quality of learning media used, the better students' learning outcomes in math learning.

For educators/lecturers, choosing the learning media must first trace difficulties or factors such as what causes students to lack understanding of the material described. It is very important to be designed and thought about because it influences students' learning outcomes in class. It is proven through research of (Solihah, 2020), (Suhendri \& Mardalena, 2013), and (Mutammimah, 2020) states that learning media can have a significant influence on student's learning outcomes in the classroom so that there is an increase in student learning outcomes in the classroom. 
In addition, please note that students are happy with online learning, but they still have difficulty understanding the material. Because of obstacles in online learning, such as (1) learning media used by lecturers are often irregular; for example, today's meeting uses learning videos, and subsequent meetings only send Attachments to PowerPoint files without learning videos. Because in the attachment of PowerPoint files, there is only writing without being presented video, students do not understand the material provided, (2) reduced motivation to learn can affect the concentration of students slowly so that some of them feel bored and sleepy during online learning. (3) Online learning provides easy access for students so that the emergence of lazy attitudes in students to understand the whole material, and (4) lecturers are never learning through media conferences, such as Zoom, google meet and other applications so that students cannot interact directly with lecturers like regular face-to-face on campus.

\section{Conclusion}

From the three materials tested, students had difficulty understanding and solving problems in numerical method materials for solving first-rate differential equations, especially in indicators of lack of accuracy in answering questions. Thus, lecturers can conduct a thorough evaluation of learning, especially on the material, so that students can reduce mistakes made in answering questions, both easy and difficult. The role of educators/lecturers is needed so that the continuity of mathematics learning remains balanced. It can also be seen from the learning media used by lecturers during lectures. Lecturers tend to use learning media in learning videos (offline or online) where most students are very interested and like learning media. So lecturers can develop and innovate into new learning media to bring the classroom atmosphere alive, and students become active and participate in learning mathematics in the classroom. Thus, this research is useful for educators/lecturers in observing the condition of student learning difficulties given the use of learning media to motivate students to be active in learning advanced differential equation courses during the Covid-19 pandemic.

\section{References}

Abdurrahman, M. (2010). Pendidikan Bagi Anak Berkesulitan Belajar (Cet.2). Jakarta: PT Rineka Cipta.

Anitasari, A., Pandansari, O., Susanti, R., Kurniawati, K., \& Aziz, A. (2021). Pengaruh Efikasi Diri Terhadap Perilaku Menyontek Siswa Sekolah Dasar selama Pembelajaran Daring. Jurnal Penelitian Ilmu Pendidikan, 14(1), 82-90. https://doi.org/10.21831/jpipfip.v14i1.37661

Aziz, B. F. A. (2020). Analisis Tingkat Kemampuan Mahasiswa dalam Menjawab Soal Persamaan Diferensial berdasarkan Taksonomi SOLO dan Analisis Kesalahan berdasarkan Kriteria Watson (UIN Sunan Gunung Djati Bandung). UIN Sunan Gunung Djati Bandung. Retrieved from http://digilib.uinsgd.ac.id/33014/

Bronson, R., \& Costa, G. (2007). Shaum's Outlines : Persamaan Diferensial (Third Edit). Jakarta: Erlangga.

Jamal, F. (2014). Analisis Kesulitan Belajar Siswa dalam Mata Pelajaran Matematika pada Materi Peluang Kelas XI IPA SMA Muhammadiyah Meulaboh Johan Pahlawan. Jurnal MAJU (Jurnal Pendidikan Matematika), 1(1), 18-36. Retrieved from http://www.ejournal.stkipbbm.ac.id/index.php/mtk/article/view/232

Khurriyati, Y., Setiawan, F., \& Mirnawati, L. B. (2021). Dampak Pembelajaran Daring terhadap Hasil Belajar Siswa MI Muhammadiyah 5 Surabaya. Jurnal Ilmiah "Pendidikan Dasar," 8(1), 91-104. https://doi.org/http://dx.doi.org/10.30659/pendas.8.1.91-104

Kurniasih, P., Limbong, E. G., \& Handayani, D. (2019). Infografis Alasan Menyontek dan Tipe-Tipe Penyontek: Pandangan Etika Mengenai Perilaku Menyontek. Jurnal Desain, 
6(2), 112. https://doi.org/10.30998/jurnaldesain.v6i2.2969

Mustakim. (2020). Efektivitas Pembelajaran Daring Menggunakan Media Online Selama Pandemi Covid-19 pada Mata Pelajaran Matematika. Al Asma: Journal of Islamic Education, 2(1), 1-12. https://doi.org/https://doi.org/10.24252/asma.v2i1.13646

Mutammimah. (2020). Meningkatkan Hasil Belajar Siswa Melalui Media Pembelajaran Quizizz Pada Materi Dinamika Rotasi Selama Pandemi. Prosiding SENA: Seminar Nasional Ahlimedia, 1(1), 19-25. https://doi.org/https://doi.org/10.47387/sena.v1i1.34

Ningsih, Y. L., \& Rohana, R. (2018). Pemahaman Mahasiswa terhadap Persamaan Diferensial Biasa Berdasarkan Teori APOS. Jurnal Penelitian Dan Pembelajaran Matematika, 11(1), 168-176. https://doi.org/10.30870/jppm.v11i1.2995

Nurlaili, \& Rifanti, U. M. (2020). Analisis Kesalahan dalam Penyelesaian Permasalahan Persamaan Diferensial Linier Orde Pertama: Studi Kasus Mahasiswa Teknik Telekomunikasi ITTP. Jurnal Gantang, 5(1), 29-37. https://doi.org/https://doi.org/10.31629/jg.v5i1.1742

Nuryadi, \& Bahtiar, Z. H. (2017). Pengembangan Media Pembelajaran Matematika Interaktif Menggunakan Adobe Flash CS5 Pokok Bahasan Trigonometri untuk Meningkatkan Motivasi Belajar Siswa Kelas X SMA. AlphaMath: Journal of Mathematics Education, 3(1), 12-22. https://doi.org/10.30595/alphamath.v3i1.1928

Oktavia, A., \& Khotimah, R. P. (2016). Analisis Kesulitan Mahasiswa dalam Menyelesaikan Persamaan Differensial Tingkat Satu. Prosiding, (KNPMP I Universitas Muhammadiyah Surakarta, 12 Maret 2016), 99-108. Retrieved from http://hdl.handle.net/11617/6946

Solihah, A. (2020). Pengaruh Model Pembelajaran terhadap Hasil Belajar Matematika Ditinjau dari Kemandirian Belajar Siswa. Cakrawala Pedagogik, 4(1), 11-18. https://doi.org/https://doi.org/10.51499/cp.v4i1.127

Suhendri, H., \& Mardalena, T. (2013). Pengaruh Metode Pembelajaran Problem Solving terhadap Hasil Belajar Matematika Ditinjau dari Kemandirian Belajar. Jurnal Formatif, 3(2), 105-114. https://doi.org/http://dx.doi.org/10.30998/formatif.v3i2.117

Trisniawati, T., Muanifah, M. T., Rhosyida, N., \& Hidayat, R. A. (2021). Eksplorasi Hasil Belajar Matematika melalui Penerapan Sistem Pembelajaran Daring (SIPEDAR) di Masa Pandemi Covid-19. AlphaMath: Journal of Mathematics Education, 7(1), 57-63. https://doi.org/10.30595/alphamath.v7i1.10195

Tsurayya, A., \& Kurnianingrum, N. J. (2021). Analisis Kemampuan Pemahaman Konsep Mahasiswa dalam Menyelesaikan Soal Persamaan Diferensial Ditinjau dari Gaya Kognitif. Jurnal Cendekia: Jurnal Pendidikan Matematika, 5(3), 2385-2397. https://doi.org/https://doi.org/10.31004/cendekia.v5i3.866

Yudianto, A. (2017). Penerapan Video Sebagai Media Pembelajaran. 234-237. Sukabumi: Muhammadiyah University of Sukabumi. Retrieved from http://eprints.ummi.ac.id/354/

Yusnanda, Helmi, \& Yudhi. (2019). Transformasi Laplace Modifikasi untuk Menyelesaikan Beberapa Persamaan Diferensial Biasa Linear. Buletin Ilmiah Mat. Stat. Dan Terapannya (Bimaster), 8(1), 53-62. https://doi.org/http://dx.doi.org/10.26418/bbimst.v8i1.30522 